\title{
Capitalism and Class in the Gulf Arab States
}

\author{
Adam Hanieh
}

New York: Palgrave Macmillan, 2011. 266 pages.

To label Adam Hanieh's Capitalism and Class in the Gulf Arab States an afterstudy of the 2008 financial crisis is a grossly unfair assessment. While the book does explore the implications of the Gulf states' financial slump, it also provides a nuanced analysis of their class structures and relation to the global capital system. The exponential growth of the Gulf Cooperation Council (GCC) states is the book's main subject; however, Hanieh dexterously avoids the common errors involved in the region's economic analysis and thus adds to the corpus of literature pertaining to both the GCC and the wider global economy.

The class structures and wealth prevailing in the GCC are often seen as an outcome of the states being oil rich. Hanieh problematizes this narrative by positing that this wealth and structuring is not "accidental" and that while oil is undeniably important, it is not the sole reason for the region's situation. He urges the reader to look beyond the hydrocarbon wealth, because "much like its desert cousin, the mirage - what visitors actually see in the oil-fueled boom is not the full picture" (p. 2).

Hanieh's choice of viewing the GCC holistically, instead of addressing specific nation-states, is significant. The "internationalization" of the local economy and class structure results in the dissolution of class boundaries among the states and paves the way for capitalism. But at the same time, however, capitalism needs to be valorized in a coherent and material time and space. This valorization has taken the special form of the regional GCC and becomes the study's focal point. This regionalization has displaced "power upwards to the regional scale, weakening the ability of the individual member states to control the movement of goods and capital within the intra-GCC space" (p. 104).

The author also problematizes the "rentier-state" theory through a Marxian framework. He urges the reader not to consider the state, and particularly the states of the Gulf nations, as a "thing" or an automatic reflection of the capitalist class, but rather as "a particular expression of class formation" (p. 12). This also implies that the state has greatly facilitated the development of the GCC's prevailing "hot-house" economy (p. 15).

The study's regional nature culminates in the analysis of "Khaliji" capital. In the Gulf states, the internationalization of capital manifests itself in a regional form as the "circuits of capital are themselves elaborated at the re- 
gional scale" (p. 103). The latter half of the book concentrates on the boom during the post-2000 and pre-2008 period, in which all the circuits of capital, namely, productive, commodity, and finance, were informed by Khaliji capital. Construction and manufacturing, in particular, formed "key moments around which capitalist class formation preceded in the productive circuit over the post-2000 period" (p. 111). The Saudi-Emirati axis is identified as the main spatial zone in which this accumulation took place.

The impact of this capital is not simply confined to the GCC, for it has very real implications for the wider Middle East. In fact, the aftermath of the American invasion of Iraq and the implementation of the Bremer laws has resulted in a mass influx of Khaliji capital into the region. Hanieh contends that the flow of capital is currently being analyzed through the neo-liberal, positivist framework of the World Bank and the International Monetary Fund, which "obfuscates the fact that capital is not a sum of money, but rather a social relation grounded in the extraction of value" (p. 152). Thus the "development of class and state throughout the Middle East is deeply wrapped up in the formation of Khaliji capital" and should be understood from a regional perspective (p. 164).

The author skillfully implicates the Gulf states in the 2008 financial crisis by labeling them as "junior partners" integrated into the production of the global capital system. In the wake of the 1973-74 rise in oil prices, this excess cash (or petrodollars) fuelled the "financialization" of the capital system, thereby placing these states squarely in the middle of the particular form that the "financialized"/internationalized global market has assumed.

According to him, the Gulf states also facilitated the consolidation of American hegemony as a financial/political powerhouse. The GCC, particularly Saudi Arabia, colluded with the United States following the spike in oil prices to maintain the role of the American dollar as the major currency in the circulation of debt. Furthermore, the debt trap in which most countries of the South found themselves was a direct result of the processes taking place within the Gulf region.

Hanieh posits that the class formation in the Gulf region has serious implications because it is so intimately tied to the larger global market. The GCC's centrality means that its working class has the potential to significantly threaten the global accumulation of capital, which is partly why the working class of these states consists of temporary, migrant workers with no citizenship rights. This is coupled with the redirection of oil revenues to merchant families, who have subsequently formed a nexus with the state through alliances with the ruling families. The consolidation of the ruling class is 
crystallized alongside the development of the capital circuit in the region, as the largely migrant labor becomes increasingly alienated.

In conclusion, Hanieh's incisive analysis of the economic realities confronting the GCC and their correlation to the global market offers a fresh perspective on the economic woes of the contemporary world. The author's estimation of the 2008 financial crisis and his constant emphasis on the "interdependent" nature of global capital (with special reference to the GCC) compels the reader to understand capitalism as an enterprise that cannot sustain itself within the boundaries of the nation-state. While the specifics of the future might be uncertain, it remains clear that the class structuring of Gulf states will remain oriented toward the accumulative tendencies of global capital.

Junaid S. Ahmad 